\title{
HUBUNGAN TINGKAT PENDAPATAN KELUARGA DENGAN PRESTASI BELAJAR SISWA SMK TELADAN MEDAN \\ Oleh \\ Dorlince Simatupang*
}

\begin{abstract}
Abstrak
This research aim at: (1) obtaining data on level of family income gradeII students of SMK of FieldByword, (2) findingout achievement of the student grade II SMK offield Byword and,(3)finding out whetherlevel of family income related with student's achievement of grade II SMK of Field by word. The research population is student of grade II SMK of Field Byword amount to 50 people, and employing total sampling. Data collecting is used by a Questionnare. Data are analyzed with correlation test $(r)$ and test the level significant 95\%. The data analyzedwith correlation test and continued with the test of significant correlation $(t)$ indicate that the correlation coefficient between level of family income with the achievement (rxy) is equal to 0,809 and result of test $t$ calculated: 9,47 and t tables of: 1,68. From the test result that $t$ calculated is bigger than tables of $N$ with the level of significant $95 \% . T$ calculated from $t$ off hence hypothesis (ho) refused and alternative hypothesis (ha) accepted. This means that level of family income have positive relation with the student achievement. The result of this research indicate that family income with the mean score 2,76 and correlation coefficient indicate that the level of family incomegive significant contribution to student's achievement. Thereby result of this research indicate that the level family income represent one of determinant aspect in improving student's achievement.
\end{abstract}

\section{Kata Kunci: Pendapatan Keluarga, Prestasi Belajar}

\section{A. Pendahuluan}

Pembangunan suatu bangsa harus disertai dengan pembangunan manusianya. Untuk pembangunan manusianya. Untuk pembangunan manusia, pembangunan sector pendidikan merupakan factor utama, karena pendidikan merupakan suatu modal dasar bagi setiap manusia dalam rangka mencerdaskan bangsa. Pelaksanaan pendidikan harus ditopang dengan kerjasama yang baik dari keluarga(orang tua), sekolah(guru) dan pemerintah.

Keluraga(orang tua) merupakan tempat pendidikan yang pertama dan terutama bagi anak. Pendidikan keluarga menjadi dasar pembentukan pribadi anak melihat, mendengar dan merasakan serta meniru sikap dan tindakan yang ditampilkan orangtua dan akan kelak ditiru oleh anak. Baik tidaknya

\footnotetext{
* Dosen Fakultas Ilmu Pendidikan, Universitas Negeri Medan
} 
pendidikan keluarga akan menjadi cermin dalam pembentukan kepribadian anak. Orangtua sebagai pendidik yang pertama dan terutama hendaknya menjadi contoh kepada anak baik dalam bersikap, bertindak, berbicara dan sebagainya.

Dalam kehidupan keluarga masalah pendapatan orangtua turut menentukan perkembangan potensi anak, baik secara fisik maupun phsikis. Khususnya dalam memenuhi kebutuhan anak dalam kelengkapan pendidikan seperti: kelengkapan sarana belajar, kesehatan sandang-pangan turut mendukung keberhasilan anak dalam belajar. Sebaliknya jika pendapatan orangtua rendah maka penyediaan akan kebutuhan anak kurang, juga akan mempengaruhi pada kelambatan prestasi anak. Hal ini sesuai dengan pernyataan The Liang Gie(1986) yang mengatakan bahwa semakin lengkap alat-alat perlengkapan belajar seorang siswa maka akan semakin baik ia belajar.

Selanjutnya orangtua juga dituntut untuk berusaha membangkitkan motivasi belajar anak yakni dengan mengawasi anak dirumah seperti mengawasi anak dalam mengerjakan pekerjaan rumah dan dengan mengarahkan anak sesuai dengan bakat dan niatnya.

Hasil informasi dari guru mengatakan bahwa sebagian besar murid di sekolah ini berasal dari kelurga yang kurang mampu. Hal ini dapat dilihat dari keterlambatan siswa membayar uang sekolah, buku bacaan sangat minim dan bahkan ada siswa pulang sekolah harus menarik becak untuk memenuhi kebutuhan hidupnya. Salah satu penyebab rendahnya prestasi belajar siswa diduga karena siswa kurang mendapat dukungan akan kebutuhan anak dalam belajar.

Orangtua sebagai factor penentu yang bertanggung jawab memenuhi kebutuhan keluarga harus bekerja kerasuntuk memperolehpendapatan. Penghasilan keluarga tergantung padapekerjaan mereka. Hal itudapat dilihat dari pendapatan pokok dan pendapatan tambahan. Hasil pendapatan ini turut menentukan keberhasilan anak dalam belajar khususnya dalam memenuhi kebutuhan akan kelengkapan sarana belajar anak. Keluarga juga mempunyai arti dan kedudukan penting dalam mendidik dan membimbing anak khususnya dalam memberi kasih sayang, perhatian dan perlindungan kepada anak.

Dalam melaksanakan tugas sebagai orngtua, keluarga juga berfungsi menanamkan ajaran agama yang diyakini oleh orangtua dan mengnalkan nilai-nilai dansikap yang dianut masyarakat dan mentransfer peranannya kemasa yang akan datang. Dengan melihat pentingnya peranan keluarga dalam upaya membina dan 
mengembangkan potensi anak, maka orangtua juga menjadi salah satu penentu akan keberhasilan anak belajar di sekolah.

Prestasi belajar siswa disekolah dipengaruhi dua faktor yaitu dari dalam diri anak juga dari luar diri anak. Faktor dari dalam diri anak seperti kondisi kesehatan, inteligensi, minat, motivasi, cita-cita daris eseorang anak. Faktor dari luar seperti: pengaruh keluarga, sekolah dan masyarakat sebagai lingkungan anak. Dengan melihat kedua faktor ini keluarga sangat berperan dan turut bertanggung jawab akan pembinaan dan pengembangan prestasi belajar anak, baik dalam penyediaan sarana, prasarana, motivasi dan arahan yang dibutuhkan anak, sehingga keluarga benar-benar menjadi tempat yang nyaman tentram bagi kehidupan anak.

Penelitian ini dilaksanakan di SMK Teladan Medan pada kelas II Jurusan Elektronika tahun ajaran 2010/2011 semester genap. Populasi dalam penelitian ini adalah siswa kelas II Elektronika sebanyak dua kelas yaitu kelas II $\mathrm{TE}^{1}$ dan II $\mathrm{TE}^{2}$ dengan jumlah populasi 50 orang. Sampel dalam penelitian ini adalah sampel total.

Metode yang digunakan dalam penelitian ini adalah metode deskriptif. Adaun variabel penelitian ini adalah 1) Tingkat pendapatan keluarga sebagai variabel bebas dan 2) Prestasi belajar siswa sebagai variabel terikat. Tingkat pendapatan orang tua dapat dilihat dari pekerjaan dan penghasilan pokok serta penghasilan tambahan yaang didapat untuk memenuhi kebutuhan hidup keluarga. Prestasi belajar siswa dapat dilihat dari hasil belajar yang dicapainya berdasarkan penilaian guru kepada siswa sesuai dengan kemampuan dan kecakapan yang dicapai dalam setiap bidang studi.

Untuk persyaratan analisa data dalam setiap perubahan maka dilakukan uji persyaratan dengan menggunakan: 1) Uji normalitas yang dilakukan dengan menggunakan rumus Chi kuadrat $\left(\mathrm{X}^{2} \mathrm{~h} 1\right)$ dan 2) Uji kelinearan dan keberatian.

Persamaan Regresi

Setelah dapat diuji hasil persyaratan analisis maka selanjutnya menganalisis data dengan 3 langkah, yaitu:

1) Analisa koefisien korelasi jenjang nihil dengan rumus Product Moment, untuk menguji hipotesa pertama daan kedua.

2) Analisis korelasi ganda dan analisis variansi untuk menguji hipotesis ketiga dan

3) Untuk mengetahui hubungan antara variabel bebas dan variabel terikat dengan mengontrol variabel bebas lainnya yang digunakan dengan menggunakan rumus korelasi parsial. Teknik 
analisis data untuk taraf signifikansi dalam penelitian ini adalah 0,05 .

\section{B. Hasil dan Pembahasan}

Berdasarkan dari analisis dekriptif penelitian, maka dapat dijelaskan pada tabel berikut ini.

Tabel 1. Jenis Pekerjaan Orang Tua

\begin{tabular}{|c|l|c|c|}
\hline No & \multicolumn{1}{|c|}{ Pertanyaan } & Jumlah Skor & Rata-rata \\
\hline 1 & Pekerjaan Orang Tua & 109 & 2,18 \\
\hline 3 & $\begin{array}{l}\text { Orang Tua yang memiliki } \\
\text { Pekerjaan Sampingan }\end{array}$ & 106 & 2,33 \\
\hline \multicolumn{2}{|c|}{$\begin{array}{c}\text { Jumlah } \\
\text { Tumb }\end{array}$} & 215 & 4,51 \\
\hline
\end{tabular}

Tabel di atas menunjukkan Bahwa pekerjaan orang tua dapat dikategorikan kurang baik karena memiliki rata-rata 2,18 dan orang tua yang memiliki pekerjaan sampingan juga kurang baik karena memiliki rata-rata 2,33.

Tabel 2. Jumlah Penghasilan Orang Tua
\begin{tabular}{|l|l|c|c|}
\hline No & \multicolumn{1}{|c|}{ Pertanyaan } & $\begin{array}{c}\text { Jumlah } \\
\text { Skor }\end{array}$ & Rata-rata \\
\hline 2 & Penghasilan orang tua & 106 & 2,12 \\
\hline 4 & $\begin{array}{l}\text { Pendapatan sampingan } \\
\text { orang tua }\end{array}$ & 98 & 1,98 \\
\hline 5 & $\begin{array}{l}\text { Pendapat siswa tentang } \\
\text { penghasilan orang tua }\end{array}$ & 134 & 2,68 \\
\hline 6 & $\begin{array}{l}\text { Penghasilan orang tua yang } \\
\text { dapat memenuhi kebutuha } \\
\text { fasilitas belajar anak }\end{array}$ & 123 & 2,46 \\
\hline \multicolumn{2}{|c|}{ Jumlah } & 461 & 9,24 \\
\hline
\end{tabular}

Tabel di atas menunjukkan bahwa penghasilan orang tua dapat dikategorikan kurang baik dengan rata-rata 2,12 dan pendapatan sampingan orang tua rata-rata 1,98. Pendapat anak akan penghasilan orang tuajuga kurang dengan rata-rata 2,68 dan pemenuhan akan kebutuhan daam fasilitas belajar juga kurang dengan rata-rata 2,46 .

\begin{tabular}{|c|c|c|c|}
\hline No & Pertanyaan & $\begin{array}{l}\text { Jumlah } \\
\text { Skor }\end{array}$ & Rata-rata \\
\hline 7 & $\begin{array}{c}\text { Jumlah Tanggungan Orang } \\
\text { tua }\end{array}$ & 150 & 3,00 \\
\hline \multicolumn{2}{|r|}{ Jumlah } & 150 & 3,00 \\
\hline
\end{tabular}

Tabel di atas menggambarkan bahwa jumlah tanggungan orang tua dalam keluarga SMK Teladan Medan memiliki skor 150 dengan rata-rata 3,0 dengan kategori baik. 


\begin{tabular}{|c|c|c|c|}
\hline No & Pertanyaan & $\begin{array}{c}\text { Jumlah } \\
\text { Skor }\end{array}$ & Rata-rata \\
\hline 8 & Kondisi Rumah Orang tua & 151 & 3,02 \\
\hline 9 & $\begin{array}{l}\text { Penerangan yang digunakan di } \\
\text { rumah }\end{array}$ & 194 & 3,88 \\
\hline 10 & Jenis air yang digunakan & 165 & 3,3 \\
\hline 11 & Sarana Pembuangan Tinja & 156 & 3,12 \\
\hline 12 & $\begin{array}{l}\text { Tingkat Kebisingan di } \\
\text { lingkungan rumah }\end{array}$ & 163 & 3,62 \\
\hline 13 & Tingkat & 198 & 3,96 \\
\hline & Jumlah & 1027 & 20,54 \\
\hline
\end{tabular}

Tabel di atas menunjukkan bahwa keadaan keadaan rumah orang tua siswa dapat dikategorikan baik.

Tabel 5. Transportasi yang digunakan siswa
\begin{tabular}{|c|l|c|c|}
\hline No & \multicolumn{1}{|c|}{ Pertanyaan } & $\begin{array}{c}\text { Jumlah } \\
\text { Skor }\end{array}$ & Rata-rata \\
\hline 14 & $\begin{array}{l}\text { Transportasi yang digunakan } \\
\text { siswa }\end{array}$ & 126 & 2,52 \\
\hline 15 & Jarak dari rumah ke Sekolah & 152 & 3,04 \\
\hline 16 & $\begin{array}{l}\text { Kendaraan yang digunakan Ke } \\
\text { sekolah }\end{array}$ & 82 & 1,64 \\
\hline \multicolumn{1}{|c|}{ Jumlah } & 360 & 7,20 \\
\hline
\end{tabular}

Tabel diatas menggambarkan bahwa transportasi yang digunakan siswa untuk berangkat ke sekolah kurang baik.

\begin{tabular}{|c|c|c|c|}
\hline No & Pertanyaan & $\begin{array}{l}\text { Jumlah } \\
\text { Skor }\end{array}$ & Rata-rata \\
\hline 17 & Kebutuhan Pendidikan Anak & 136 & 2,72 \\
\hline 18 & $\begin{array}{l}\text { Ketersediaan Orang tua dalam } \\
\text { membeli Buku Pelajaran }\end{array}$ & 151 & 3,02 \\
\hline 19 & Jumlah buku bacaaan siswa & 137 & 2,74 \\
\hline 20 & Cara memperoleh buku bacaan & 148 & 2,96 \\
\hline 21 & Peralatan belajar siswa & 141 & 2,82 \\
\hline 22 & Sarana yang dibutuhkan siswa & 117 & 2,34 \\
\hline 23 & $\begin{array}{l}\text { Bimbingan orang tua kepada } \\
\text { siswa di rumah }\end{array}$ & 128 & 2,56 \\
\hline 24 & Perhatian orang tua pada siswa & 136 & 2,72 \\
\hline & Jumlah & 1094 & 21,88 \\
\hline
\end{tabular}


Dalam tabel diatas menunjukkan bahwa fasilitas belajar yang didapat oleh anak kurang baik.

\section{Hubungan Tingkat Pendapatan Keluarga Terhadap Prestasi Belajar Siswa (y)}

Analisis koefisien korelasi parsial antara $\mathrm{x}$ dan $\mathrm{y}$ sebesar 0,809 dan 0,279 . Untuk jumlah responden 50 orang dengan $r$ tabel sebesar 0,279 pada taraf signifikan $\mathrm{x}=0,05$. Dengan demikian harga t hitung lebih besar dari t tabel yakni: 0,809 > 0279. Untuk uji keberartian koefisien korelasi diperoleh $\mathrm{t}$ hitung lebih besar dari t tabel yakni: 9,47>1,68.

Berdasarkan kriteria penerimaan dan penolakan hipotesis maka hipotesis pertama yang menyatakan terdapat hubungan linier yang berarti antara tingkat pendapatan keluarga terhadap prestasi belajar siswa maka hipotesis diterima.

Serta berdasarkan perolehan dari hasil analisis deskriptif dan setelah diadakan pengujian-pengujian maka secara umum ditemukan bahwa tingkat pendapatan keluarga dengan hasil belajar siswa SMK Teladan kelaas II Jurusan listrik mempunyai hubungan yang erat.

Dari hasil analisis korelasi parsial tersebut ditemukan terdapat hubungan yang signifikan antara variaabel $\mathrm{x}$ dengan variabel y yakni sebesar 0,906 yang berarti prestasi belajar akan meningkat jika tingkat pendapatan keluarga semakin tinggi, namun sebaliknya jika tingkat pendapatan keluarga menurun maka prestasi belajar siswa akan menurun.

Berdasarkan pedoman diatas menggambarkan bahwa koefisien korelasi hubungan tingkat pendapatan dengan prestasi belajar siswa termasuk dalam korelasi tinggi yaitu dengan hasil perhitungan 0,809 terletak diantara 0,70- 0,90. Jika hasil perhitungan tersebut dibandingkan dengan $r$ tabel pada taraf kepercayaan $95 \%$ dan $\mathrm{N}$ sebesar 50, maka $\mathrm{r}$ hitung lebih besar dari r tabel yakni 0,809>0,279.

Selanjutnya perhitungan uji keberartian dengan "uji $t$ " diperoleh tingkat keberartian sebesar 9,47 sedangkan $t$ tabel sebesar 9,47>1,68. Dengan demikian hipotesis penelitian ini menyatakan " Ada hubungan yang positif antara tingkat pendapatan keluarga dengan prestasi belajar siswa di kelas II SMK Teladan Medan.

\section{Kesimpulan Dan Saran}

1. Kesimpulan 
a. Tingkat pendapatan keluarga merupakan suatau kondisi kesejahteraan keluarga yang meliputi kesehjahteraan lahir batin.

b. Dalam kaitannya dengan prestaasi belajar anak, tingkat pendapatan orang tua sangat menentukan. Sebab keluarga yang sejahtera akan mampu untuk menyediakan fasilitaas belajar anak, memberikan perhatian dan dorongan serta untuk mensejahterakan anak.

c. Penelitian ini membuktikan bahwa tingkat pendapatan keluarga mempunyai hubungan yang erat (signifikan) terhadap prestasi belajar siswa kelas II SMK Teladan Medan.

d. Hubungan antara variabel $\mathrm{x}$ (tingkat pendapatan keluarga) dengan variabel y (Prestasi belajar siswa) diperoleh nilai $r$ hitung sebesar 0,809.

e. Uji keberartian hipotesis yaitu dengan cara "uji $t$ " diperoleh tingkat keberartian sebesar 9,47 sedangkan nilai t tabel 1,68. Maka $\mathrm{t}$ hitung lebih besar dari $\mathrm{t}$ tabel 9,47 > 1,68. Dengan demikian hipotesis dalam penelitian ini menyatakan bahwa : Ada hubungan yang positif antara tingkat pendapatan keluarga dengan prestasi belajar siswa kelas II SMK Teladan Medan.

\section{Saran}

a. Hasil penelitan ini dapat menjadi bahan masukan kepada dunia pendidikan terutama di SMK Teladan Medan khususnya dalam proses pengambilan keputusan yang berkaitan dengan kesiswaan.

b. Pemahaman bagi para guru/ staf pengajar terhadap kondisi fisik dan psikis siswa yang bersumber dari latar belakang tingkat pendapatan keluarga perlu mendapatkan perhatian yang ekstra dalam menentukan metode belajar dan mengajar.

c. Bagi para orang tua perlu memberikan dorongan atau motivasi terhadap anak dalam prestasi belajar siswa, khususnya dalam belajar di rumah.

d. Dalam peningkatan prestasi belajar siswa sangat dipengaruhi oleh banyak faktor dan dukungan dari berbagai pihak baik institusi pendidikan, masyarakat, keluarga maupun pribadi siswa itu sendiri. Oleh karena itu kerjasama yang baik dari setiap komponen merupakan keniscayaan dalam rangka membina generasi yang berprestasi.

\section{Daftar Pustaka}

Departemen Pendidikan dan Kebudayaan, Kamus Besar Bahasa Indonesia, Balai Pustaka, Jakarta. 
Drs. Dewa Ketut Sukardi, Bimbingan dan Penyuluhan Belajar di Sekolah. Penerbit: Usaha Nasional Surabaya Indonesia.

Ghijali Abbas et al (2001). Manajemen Otonomi Daerah: Birokrasi Ekonomi Sosial. Editor: Lutfi Patimurra. Jakarta, LSKPI.

Muhibbin Syah M.Ed. (cetakan, februari 2004) Psikologi Belajar. PT. Raja Grafindo Persada, Jakarta.

Nasution Thamrin dan Nurhalijah (1989). Peranan Orang Tua Dalam meningkatkan Prestasi Belajar Anak, Jakarta: BPK Gunung Mulia.

Nawawi, Hadari (1990) Bimbingan Belajar di SMA dan Perguruan Tinggi, Jakarta: Rajawali.

Suharsimi Arikunto, Prof. Dr (cetakan ke-5 oktober, 2000). Manajemen Penelitian. Jakarta: PT. Aneka Cipta.

Sujantono (agustus 1982) Psikologi Perkembangan. Jakarta: Aksara Baru.

Tadjudin Noer Effendi (1995). Sumber Daya Manusia Peluang Kerja dan Kemiskinan. Yogyakarta: PT. Tiara Wacana. Warner dan Soesanto (1982). Pengantar Sosiologi dan Perubahan Sosial. Bandung: Bina Cipta. 